\title{
Lost and found twice: Discussion of an early post-glacial single-edged tanged point from Brodgar on Orkney, Scotland
}

\author{
Torben Bjarke Ballin ${ }^{1}$ and Hein Bjartmann Bjerck ${ }^{2}$ \\ 1. Lithic Research, Stirlingshire, U.K. and Honorary Research Fellow, University of Bradford, Bradford, UK. \\ Email: lithicresearch@btinternet.com \\ 2. The University Museum, Norwegian University of Science and Technology (NTNU), Trondheim, Norway. \\ Email: hein.bjerck@ntnu.no
}

\begin{abstract}
:
Over the last few decades it has been shown that Scotland was settled - or at least occasionally visited - during the late Upper Palaeolithic period. The finds include diagnostic artefacts of Hamburgian, Federmesser and Ahrensburgian typology, but since Livens' presentation in 1956 of three tanged arrowheads from Scotland, it has also been discussed whether northern Britain was settled or visited from the north-east, by groups belonging to the Scandinavian Fosna-Hensbacka complex. Only one of the three arrowheads presented by Livens appeared to be a Fosna-Hensbacka point, but this piece was lost immediately after the paper in which it was initially summarily described was published. However, this point - originally found at Brodgar on Orkney - has now been refound, and the authors hope that their detailed characterization and discussion of the object's date and affinity will allow the question of a possible Upper Palaeolithic-Early Mesolithic connection across Doggerland to be addressed in a more authoritative manner.
\end{abstract}

Keywords: Late Upper Palaeolithic-Early Mesolithic; Ahrensburgian; Fosna-Hensbacka; single-edged points; tanged points; Norway; Orkney; Scotland; cross-Doggerland connections; post-glacial recolonization

\section{Introduction}

In 1956, Livens (1956) presented three stray early prehistoric flint objects from Scotland, which he referred to as tanged points. They included two pieces from Orkney (one from Millfield on the Isle of Stronsay and one from Brodgar on the Orcadian Mainland), as well as one from Ballevulin on the Isle of Tiree in the Inner Hebrides. The two Orcadian implements disappeared soon after the publication of Livens' paper, whereas the piece from Tiree was lost around the turn of the millennium (latest appearance in Finlayson 1998).

All three pieces have been referred to extensively in the debate about Scotland's earliest prehistory and the post-glacial recolonization of northern Britain. There are several good

Published by the School of History, Classics and Archaeology, University of Edinburgh ISSN: 2055-0472. URL: http://journals.ed.ac.uk/lithicstudies/

This work is licensed under a Creative Commons Attribution 2.5 UK: Scotland License. 
photographs and drawings of the Tiree flint (e.g., Finlayson 1998), and it has recently been discussed by Ballin \& Saville (2003) as part of their presentation of a similar piece from Shieldaig on the shores of Loch Torridon, in the Scottish Highland region (Ballin 2002). There is little doubt that the Tiree and Shieldaig implements are proper tanged points, as they conform to a particular sub-type of Ahrensburgian tanged arrowheads (Ballin \& Saville 2003). The Millfield implement was recently refound in the collections of the Hunterian Museum, University of Glasgow, by Dr Hugo Anderson-Whymark in connection with his research into Orcadian lithic industries, and it is to be presented and discussed in connection with the publication of recent fieldwork on Stronsay (Anderson-Whymark, H. 2015). However, an apparently similar tanged object has been recovered in connection with Lee \& Woodward's excavations on Stronsay, and both tanged points belong to a group of expedient, squat points, which are formally more closely related to early prehistoric Norwegian tanged arrowheads than to the more well-executed, elongated tanged pieces known from the late Upper Palaeolithic material cultures of the north-west European continent (Figure 1) (Hamburgian, Federmesser, Brommian, Ahrensburgian, etc.; see overview in Jensen 2006).
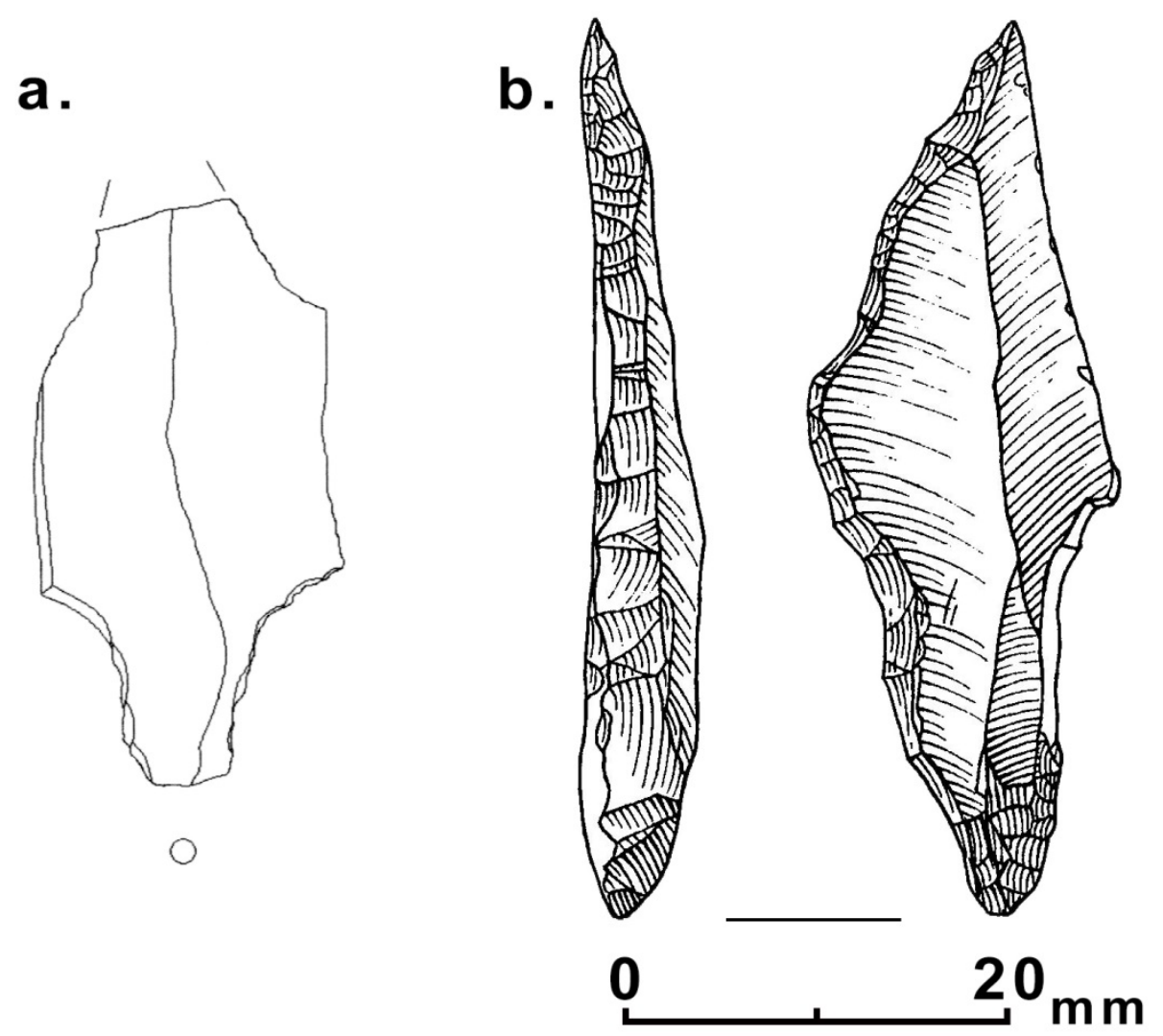

Figure 1. The expedient tanged point from Stronsay (redrawn from online illustration; SFLPS 2011) and the more sophisticated Ahrensburgian point from Tiree (drawing by Marion O’Neil; from Ballin \& Saville 2003 (after Morrison \& Bonsall 1989)).

The Brodgar piece has been touched upon by several Scottish prehistorians (inter alia Morrison \& Bonsall 1989; Saville 1996; 2000; Wickham-Jones 1994; Wickham-Jones \& Firth 2000; Edwards \& Mithen 1995), as - if it is truly a tanged point or a piece related to tanged points - it is clearly important to the discussion of the earliest settlement of Scotland, in particular the country's northern parts. However, Livens' drawing of this piece is lacking in detail, and in more recent papers (e.g., some of those listed above), new drawings have been 
made on the basis of Livens' initial drawing. For obvious reasons, the new drawings are as lacking in detail as the original illustration, and prior to this piece being refound all one could say about this piece was that a small lithic implement was found near Brodgar, Stenness parish, on the Orcadian Mainland, and that it appeared to be a tanged point or a microlith.

However, the Brodgar piece has now also been rediscovered, and in this short paper the authors aim to characterize the object in detail and present new detailed photos and drawings of the piece, as well as discuss the likely typology, diagnosticity, and affinity of the implement.

\section{The history of the Brodgar Point}

As mentioned by Livens (1956: 439), the piece presented and discussed in this paper was found on the Ness of Brodgar, Stenness parish, on the Orcadian Mainland (NGR: HY 29 13; Figure 2). The Ness is a low-lying spit of land, dividing the Loch of Stenness from the Loch of Harray. The circumstances of the find are not recorded. In recent years, the Ness of Brodgar has been associated with Middle and Late Neolithic structures (e.g., Card 2013; Towers et al. 2015), situated between two impressive later Neolithic stone circles, but the typo-technological attributes of this piece suggest that it almost certainly predates the site's Neolithic activities by several millennia.

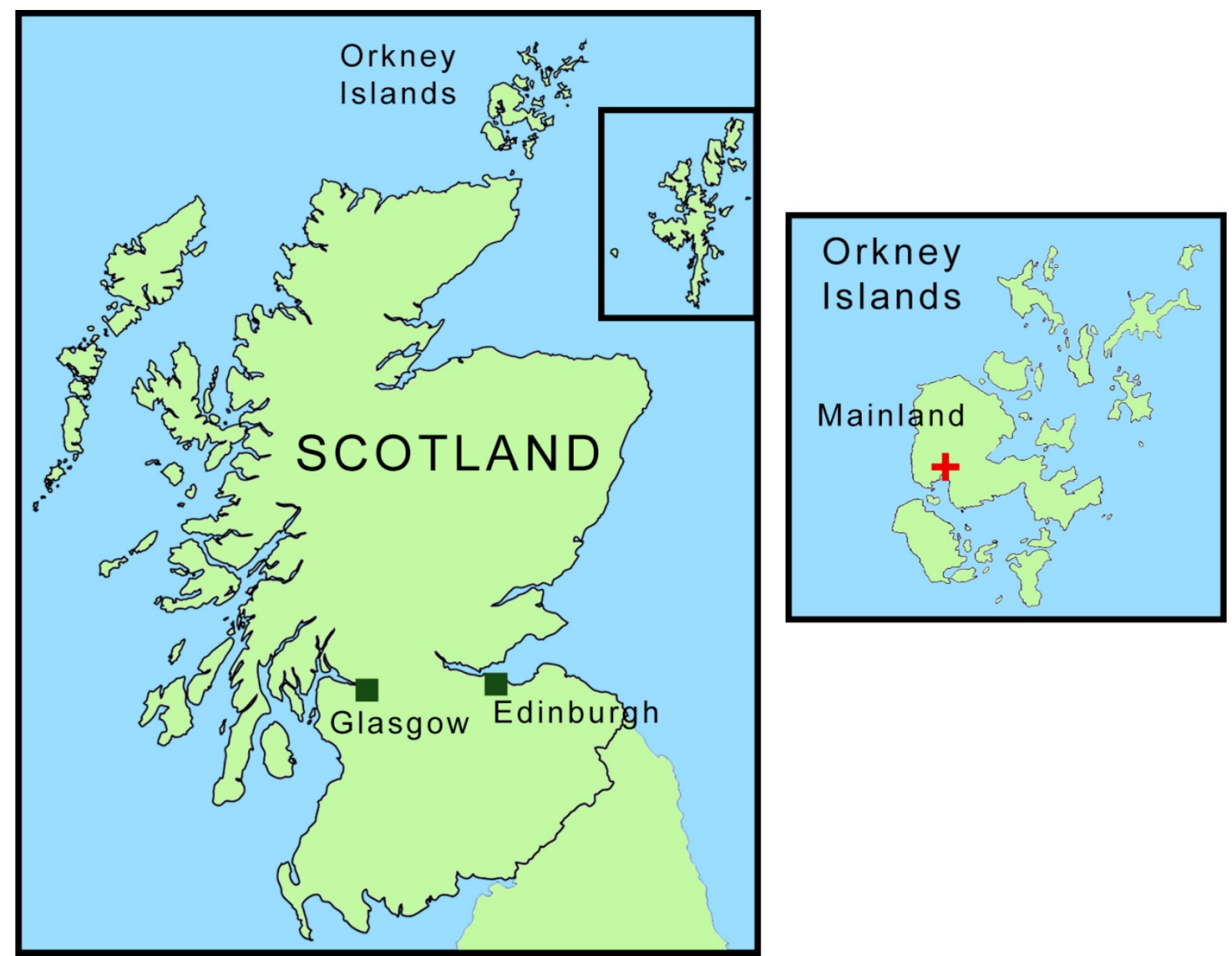

Figure 2. Location map. The cross on Mainland Orkney marks the approximate find location of the Brodgar point, on the Ness of Brodgar in Stenness parish. 
Livens himself suggests in his paper (1956) that '... there is no question of any [of the three points] being of Palaeolithic date', basing this statement on the knowledge of the day regarding post-glacial sea level fluctuations, imagining that all three locations would have been submerged at some time. However, present knowledge of sea level fluctuations in northern and western Scotland makes this less certain, with the Tiree point generally being accepted as Ahrensburgian (Ballin \& Saville 2003), and in situ early prehistoric settlement remains have recently been discovered and excavated on Stronsay, Orkney (Lee \& Woodward 2015).

In essence, the Brodgar piece has been interpreted in the archaeological literature in two ways: Saville (2000: 93) writes about this implement that '... with hindsight [it] seems perfectly acceptable as a standard Mesolithic microlith, others of which are known from the same area', whereas Wickham-Jones describes it as a 'certain tanged point' (1994: 42) or a 'possible tanged point' (Wickham-Jones \& Firth 2000: 125), and in both papers she draws parallels to armature from the Norwegian late Upper Palaeolithic-Early Mesolithic (UP-EM) period.

As mentioned above, the Brodgar piece has now 'resurfaced'. The website of the Hunterian Museum, University of Glasgow (The Hunterian Museum and Art Gallery 2006), contains dorsal and ventral photographs of the Brodgar implement, and it was through these illustrations the authors became aware of the present location of the piece. The identity of the object is immediately obvious, and it is possible that its decades-long absence may have been caused by erroneous labelling by previous generations of archaeologists or curators, as the title of the entry in the Hunterian Museum's online catalogue was 'scraper'.

\section{Characterization of the point}

In the register of the Hunterian Museum, the Brodgar implement has been given catalogue number B.1914.709. It measures $41.2 \times 11.8 \times 3.9 \mathrm{~mm}$, and it is made from finegrained, grey, lightly marbled flint. The piece is slightly discoloured (cortication sensu Shepherd 1972) from exposure to air (weathering). The quality of the raw material is better than the quality of most local Orcadian flint, and it is possible that the flint or the implement itself may represent importation, although glacial transport of the raw material cannot be ruled out entirely.

The dorsal face displays one arris which is straight and roughly parallel with the unmodified edge along the object's right lateral side, suggesting that the piece is based on a first-class broad blade from a prepared blade core. The tip is at the proximal end of the object, and the base at the distal end. The left lateral side is fully modified, straight at the base and curving slightly towards the tip. The right lateral side has straight to slightly concave modification along the basal half of the edge, leaving the tip half of this lateral side unretouched and sharp.

The photos (Figure 3) as well as the drawings (Figure 4) of the piece shows that small chips have been detached from the tip. This may be indicative of intentional sharpening of the tip similar to that seen on points from Late Early Mesolithic industries in Kunda, Butovo and Sujala sites in Russia and Finland (Kankaanpää \& Rankama 2011: 54; Sørensen et al. 2013: 30) or, the detached chips may represent impact damage to the tip. However, both explanations identify the artefact as a projectile point. Fine dorsal and ventral spin-offs along the two lateral sides, tip end, also suggest use as an arrowhead. There is no evidence of the 
application of microburin technique at the proximal end, but a microburin facet could have been removed by the modification of the tip.

\section{Discussion}

To refer the Brodgar point to one or the other specific type of armature, and then subsequently define its date and affinity, it is necessary to first discuss a number of relevant types and concepts. The questions put in connection with the discussion of this object is 1) whether it is a microlith or a tanged or single-edged point, and 2) whether it might be an Ahrensburgian tanged point or a Scandinavian-style single-edged point (inter alia Morrison \& Bonsall 1989; Saville 1996; 2000; Wickham-Jones 1994; Wickham-Jones \& Firth 2000; Edwards \& Mithen 1995).

\subsection{Tanged or single-edged point or microlith?}

To a degree, this question could be defined as meaningless, as the existing definitions allow an object (in an almost quantum mechanical manner) to be both.

A tanged point is characterized by having a tang, and 'tanged' can be defined in the following manner: 'Double-sided retouch at the distal or proximal end of an implement. The retouch forms more or less distinct shoulders with both lateral edges; adaptation of Inizan et al. (1992: 85) and Helskog et al. (1974: 36)' (see also Ballin 2000).

According to this definition, single-edged points (see below) are not tanged points sensu stricto, as the former are characterized by only having one shoulder, but they could be characterized as tanged points sensu largo, as they are defined by having a pointed, bilaterally modified hafting device at one end. This is an important point, as in the Scandinavian Upper Palaeolithic-Early Mesolithic period they are part of a formal continuum which includes tanged points sensu stricto, single-edged points and transverse arrowheads (see below).

Single-edged tanged points from Scandinavian early post-glacial sites are frequently made on blades, like the Brodgar point. These blade-based points fit our idealized notion of a 'perfect' point best, and as a result, they tend to be overrepresented in the illustrations of academic papers. However, single-edged points are just as commonly produced on flakes with adequate shapes (See Figures 5 to 7). The main defining element of a single-edged point is how the tip was prepared: an oblique or curved retouched lateral side meets the sharp lateral edge of a flake or blade, with the tip being the point where these two sides conjoin. Formal definition of implement 'types' often fails to characterize the true variation of a tool or technological tradition. Unfortunately, no detailed attribute analyses have been undertaken to define the variation within the Scandinavian single-edged point tradition. However, the fact that these artefacts represent projectile points is beyond doubt. A recent study of approximately 400 distinct single-edged points from central Norway shows that their measurements are highly confined (Breivik \& Bjerck 2015). The vast majority of the pieces are approximately 20-30 mm long and 10mm wide, although larger pieces do occur (see for example, Figure 6). This generally small size is probably a response to the specific demands experienced in connection with the use of bows and arrows. Formally, this tool type could have functioned as a cutting tool, but if that was the case, a wider size range should have been expected. 

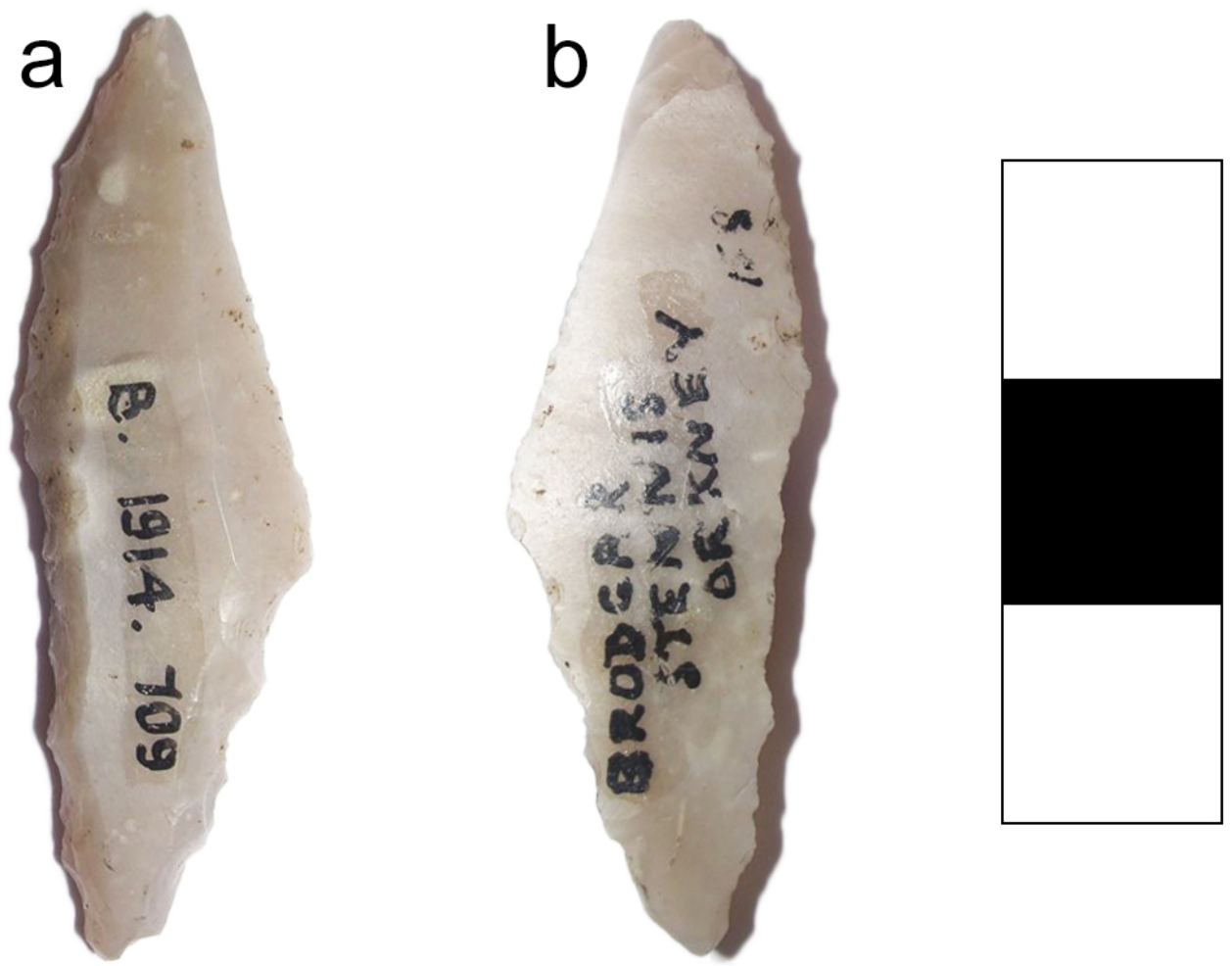

Figure 3. Dorsal and ventral view of the point. $3 \mathrm{~cm}$ scale bar. (Photos from The Hunterian Museum and Art Gallery 2006)

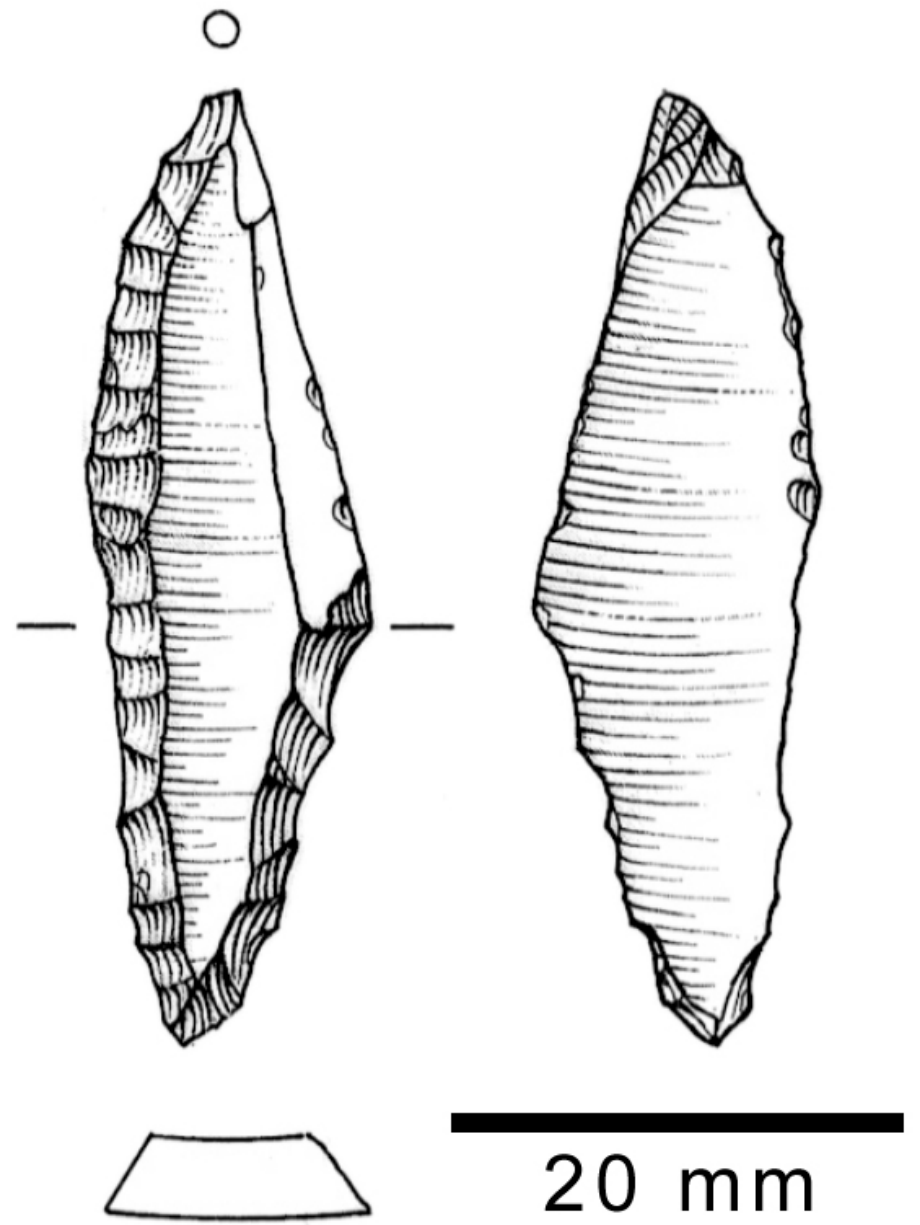

Figure 4. Dorsal and ventral view of the point (drawing: Marion O’Neil). 


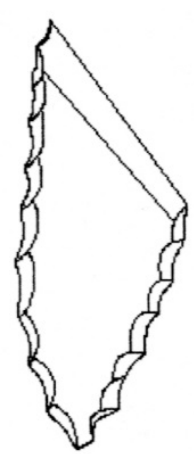

A

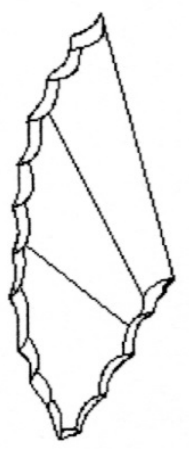

B

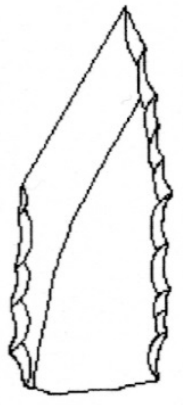

C

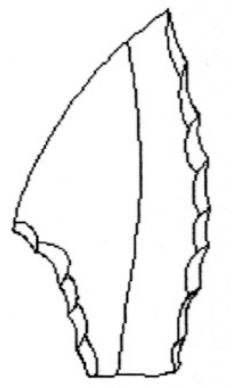

D

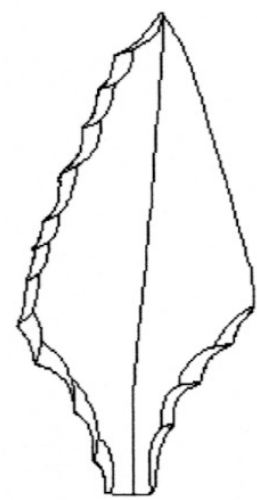

$E$

Figure 5. Sub-types of the single-edged point suggested by Møllenhus (1977) (redrawn byTorben Bjarke Ballin 2015). Today, only his Types B and D would be accepted as single-edged points.
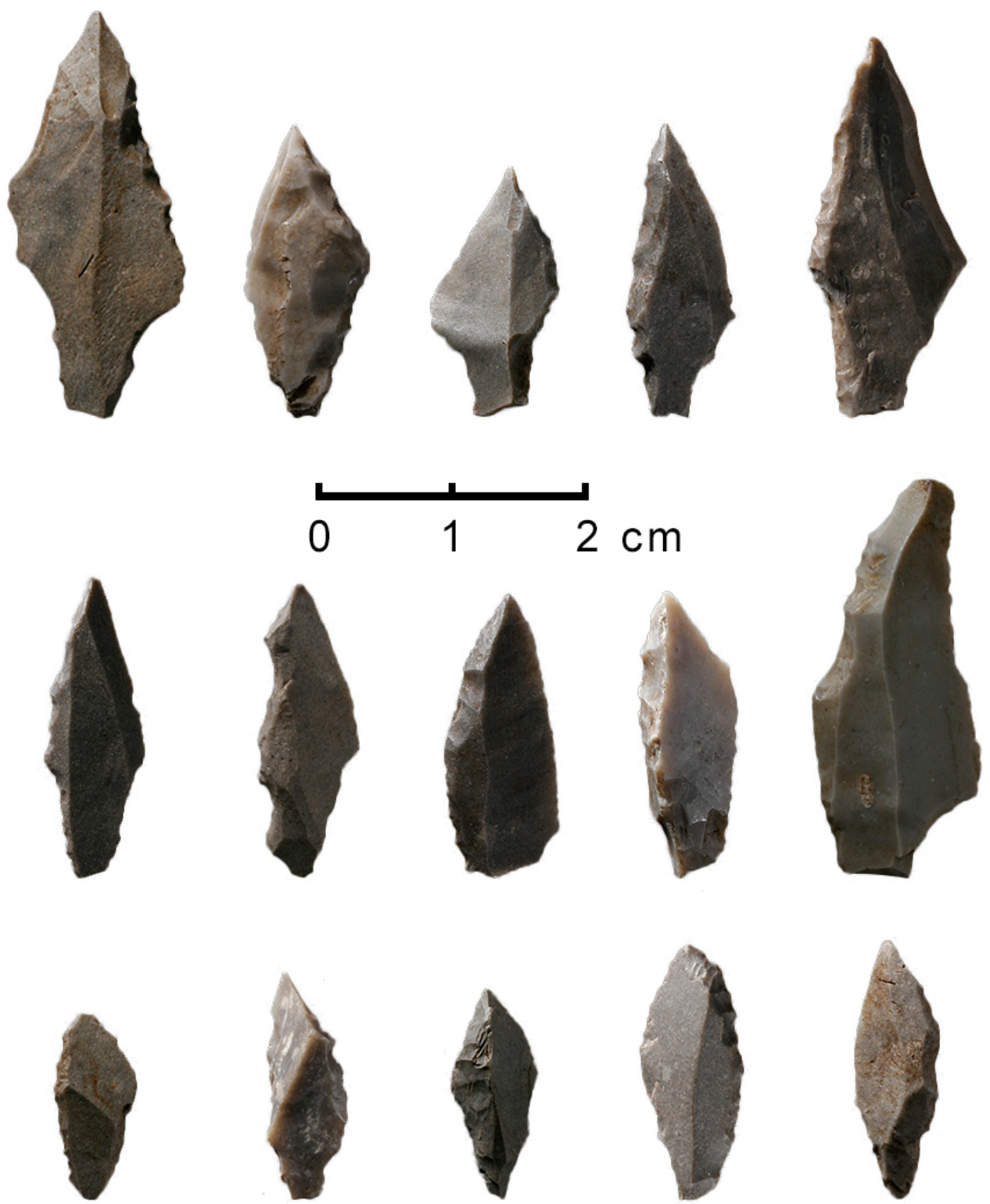

Figure 6. A selection of traditional and single-edged tanged points from Ormen Lange Locality 48, Aukra, Central Norway, c. 9100-8500 cal. BCE. Compare the first arrowhead in the second row with the Brodgar point in Figures 3 and 4. (Photo modified from NTNU Vitenskapsmuseet - Leif Inge Åstveit.) 

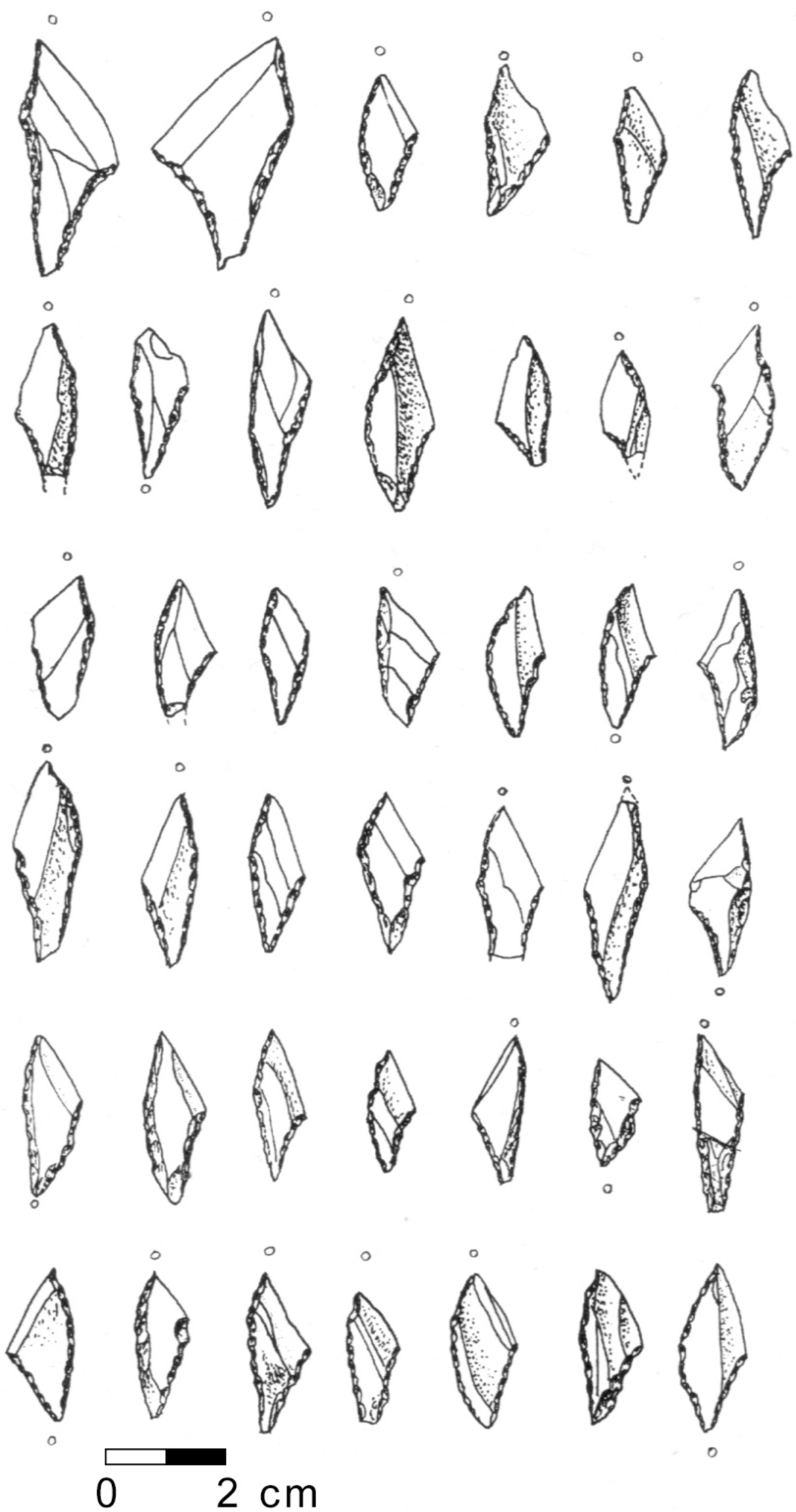

Figure 7. Single-edged points from Tosskärr in western Sweden (Hensbacka Culture) (courtesy of Hans Kindgren (Kindgren 2002: Fig. 1)). 
The term 'microlith' is defined slightly differently in different parts of north-west Europe, as in Scandinavia (Helskog et al. 1974: 26; Ballin 1996: 51) a microlith is defined as armature the tip of which was formed by removing the blank's proximal end by microburin technique, whereas in Britain (Clark 1934: 55) a microlith is defined as armature the tip of which was formed by removing the blank's proximal end by whichever means.

Kindgren's analysis of the points from Tosskärr in western Sweden, a settlement site belonging to the UP-EM Fosna-Hensbacka complex, showed that pieces belonging to the continuum of tanged, single-edged, and transverse arrowheads frequently had been formed by removing their proximal ends by microburin technique, and that many pieces still displayed a recognizable microburin facet (Kindgren 2002: 50) (See Figure 8), and in a case like this, it would be futile to attempt to distinguish between microliths on one side and pieces belonging to the continuum of tanged, single-edged, and transverse arrowheads on the other. Many of these pieces would belong to both formal categories.
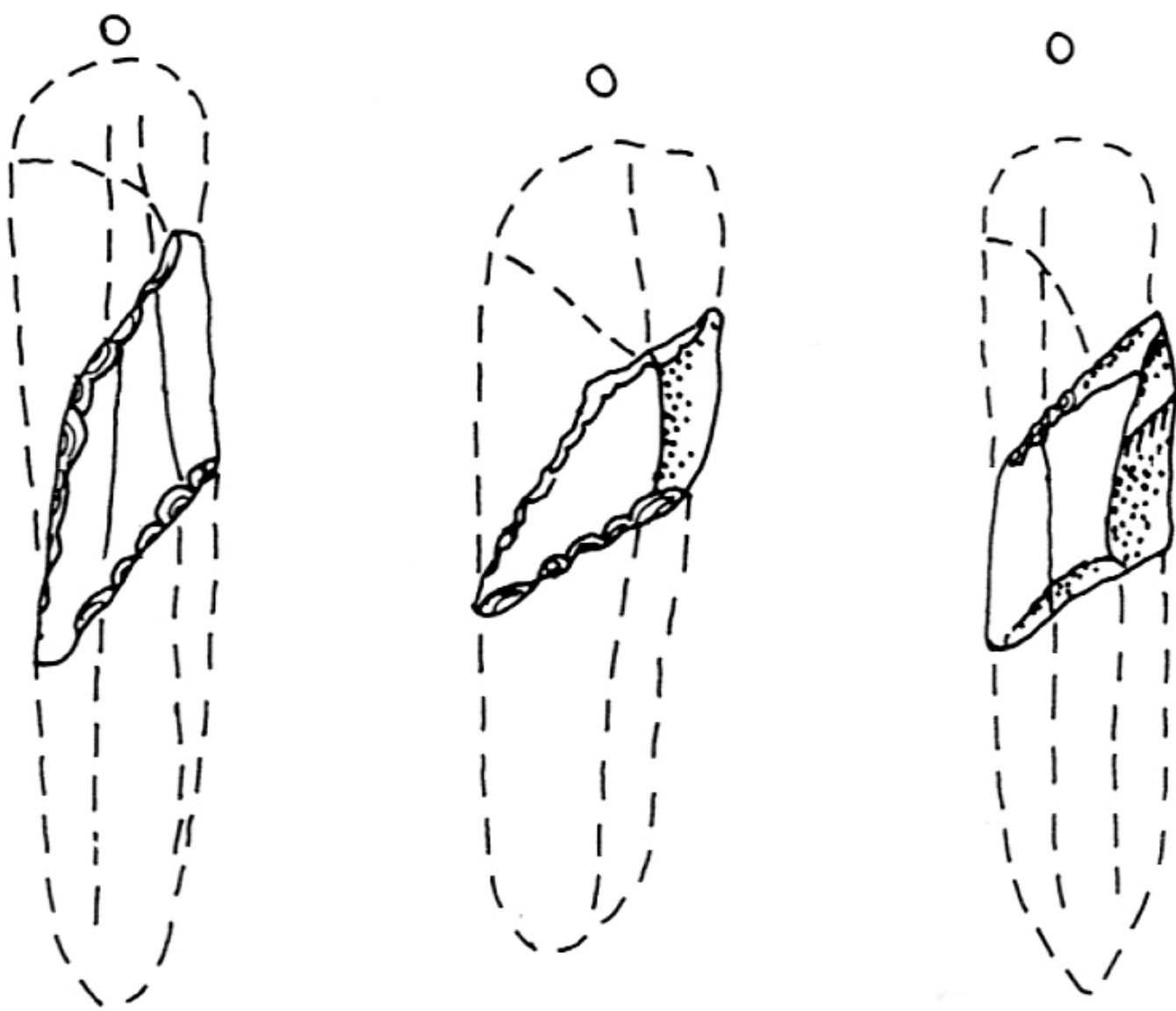

Figure 8. The production of pieces belonging to the continuum of tanged, single-edged and transverse arrowheads (courtesy of Hans Kindgren; Kindgren 2002, Fig. 2).

In terms of the Brodgar piece, it could be defined as a microlith in the sense that it has had its tip formed by removing the original blank's proximal end (although it certainly does not belong to any of the common microlith forms known from the Scottish Mesolithic; e.g., Ballin 2013), but it is also a tanged device sensu largo (although clearly not sensu stricto). 


\subsection{Ahrensburgian point or Scandinavian-style single-edged point?}

Ahrensburgian points were discussed by Ballin \& Saville (2003), who summed up Ahrensburgian point definitions in the following manner:

According to Taute (1968: 11-14), the length of a typical Ahrensburgian tanged point should not exceed $55 \mathrm{~mm}$. This means that they are mostly tanged points sensu stricto, with marked shoulders, and that they are somewhat smaller and more delicate than Scandinavian Upper Palaeolithic Hamburgian and Brommian points (Vang Petersen 1993, 76-78; Vang Petersen \& Johansen 1991). Based on the character of the tang's modification, it has been possible to define a number of sub-types. In addition, Ahrensburgian tanged points commonly have oblique ancillary retouch at the tip.

In Ahrensburgian assemblages, the tanged points may be accompanied by Zonhoven points (Schwabedissen 1954, 7; Abb. 10; 50-51; Tafel 72), which are obliquely blunted points or rhomboids, and in contrast to typical Mesolithic obliquely blunted points, like those from for example the Scottish sites Morton and An Corran (Saville 2004), they were not produced by the application of microburin technique (e.g., Schwabedissen 1954: Abb. 10; Taute 1968: Abb. 45). Some Ahrensburgian tanged points were manufactured by the application of microburin technique, although this technique was used to form the tang and not the tip. The resulting Ahrensburgian microburins therefore have not one, but two opposed lateral notches (Bang-Andersen 1995: 71; Clausen 1996: 105).

From examination of the literature on Ahrensburgian artefacts from northern and northwestern Europe it is possible to define yet another sub-type of Ahrensburgian point (Ballin \& Saville 2003: Fig. 5). This type is characterized by a tapering tang almost as long as the blade (Figure 1); one lateral side of the point is fully retouched, with the other side of the blade being un-, or only partly, retouched; the fully retouched lateral side has an almost right-angled corner, with the retouch at the tip-end of that side forming a straight, oblique truncation. In many cases, this type of tanged point resembles a rhombic Zonhoven point with an added (very long) tang.

It is worth noting that a certain amount of confusion has been created in the literature by Fischer's (1978; 1991) definition of an Ahrensburgian point sensu stricto to encompass only those examples with the tang at the distal end of the original blank. This criterion was not included in Taute's definition, indeed it is clear that his type illustration has the tang at the proximal end of the blank (Taute 1968: Abb. 1:2) (See Figure 4) and Bohmers (1956: 9) had already made reference to the base of tangs being worked to remove the bulb. As Vang Petersen \& Johansen (1991: note 7) point out, Fischer's criterion is unnecessarily restrictive and does not recognise the considerable variability of tang orientation that occurs throughout the Ahrensburgian complex.

Early attempts at defining the different members of the Fosna-Hensbacka continuum of tanged, single-edged, and transverse arrowheads was clearly somewhat intuitive, and for example the sub-types of the single-edged point suggested by Møllenhus (1977; based on excavations 1955-1965) include forms (Figure 5) which are now defined as either tanged arrowheads (his Type E) or transverse arrowheads (his Types A and C).

The term 'continuum', as used above, indicates that these types are not defined clearly against each other like for example leaf-shaped arrowheads and barbed-and-tanged arrowheads, but one type develops into another by gradual redefinition of orientation and outline. When it was realized that the relative composition of Fosna-Hensbacka assemblages 
- that is, their ratios of tanged points, single-edged points and transverse arrowheads - was highly diagnostic, attempts were made at defining the three types more precisely. In Helskog et al. (1974: 24-26) the following definitions (which are still used by Scandinavian prehistorians) were suggested:

Tanged points were defined as points with a basal tang, with the term 'tang' being defined as above. Single-edged points were defined as points with two retouched lateral sides, which diverge from the base. The longest edge is usually convex, and the shortest concave. The shortest lateral edge is less than $60 \%$ of the longest edge. Transverse arrowheads were defined as points with two retouched lateral edges which are either parallel or diverge from the base. These edges may be straight, concave or convex, and the shortest lateral edge is more than $60 \%$ of the longest edge. These points may also be subdivided according to whether the frontal edge of a piece is perpendicular to the long axis, or somewhat oblique. The '60\%-rule' was clearly defined to make it possible to distinguish unequivocally between single-edged points and transverse arrowheads. Within southern Norway, lithic research is complicated by the fact that the period around the Late Mesolithic-Early Neolithic transition is also characterized by a continuum of tanged, single-edged, and transverse arrowheads, but where the early single-edged pieces tend to have their tips at the proximal end, the later ones tend to have their tips at the distal end (Ballin 1996: 47).

The distinctive ventral modification of the Brodgar point's tip is rare in connection with points from the Scandinavian Fosna-Hensbacka tradition. However, retouch of the tip, reminiscent of that seen on the Brodgar piece, is commonly found on tanged points from Finland and Russia, such as the Kunda, Butovo and Sujala sites mentioned above. This eastern European tradition is rooted in the Swiderian or Post-Swiderian complex, which in Fennoscandia is notably later than the early post-glacial single-edged point tradition, and despite similarities in terms of tip modification, the Brodgar point is unlikely to be related to the post-Swiderian points with invasive ventral tip retouch

As shown by Sørensen et al. (2013; see also Kankanpäa \& Rankama 2011), the Fennoscandian points form part of 'the pressure blade tradition', which seems to have been introduced into Fennoscandia in the latest part of the early Mesolithic period, just before 8500 cal. BCE. The post-Swiderian tanged points are clearly not single-edged points - they are generally characterized by having ventral tip retouch, whereas typical Fosna-Hensbacka points had their tips made by unilateral oblique or curved retouch. On the basis of typotechnological attributes, as well as the likely date of the Brodgar piece (given our present knowledge of the development of Doggerland), the Brodgar point is unlikely to form part of post-Swiderian traditions, and it is more likely that the flat chips detached from the ventral face of its tip represent impact damage (compare with Fischer et al. 1984). However, it should be borne in mind that the North Sea basin represents a kind of 'dark horse' in terms of our understanding of late Upper Palaeolithic-Early Mesolithic cultural relations and lithic traditions in north-west Europe (as indicated by the recent discovery of Hamburgian style artefacts in Scotland) (see Ballin et al. 2010), and more evidence is clearly needed regarding this issue.

On the basis of these definitions, the authors agree that the Brodgar piece fits the singleedged point definition best (compare with Figure 7): 1) it is a projectile point (the size indicating use as an arrowhead); 2) it does not have clear bilateral shoulders at the base; 3) it has a proximal tip; 4) one edge is fully retouched and convex, the other partially retouched 
and slightly concave; and 5) the shortest modified edge is less than $60 \%$ of the longest edge. The use as a projectile point is further indicated by impact damage and lateral spin-offs. Points like the specimen from Brodgar were recently recovered in connection with the excavation of Locality 48, Aukra, Central Norway (Figure 6) (Bjerck 2008: 217).

\subsection{Date and affinity: An Upper Palaeolithic-Early Mesolithic 'northern Doggerland' techno-complex?}

As the Brodgar arrowhead fits the definition of single-edged points better than the definitions of any other relevant north-west European armature types, it is likely to pre-date $c$. 8,000 BCE (Bjerck 2008: 82), although the authors believe it to be considerably older. In Scandinavia, single-edged points are generally associated with the Ahrensburgian and the Fosna-Hensbacka complexes. They are common, and occasionally dominate, assemblages from this period in Norwegian (Fosna) and West Swedish (Hensbacka) contexts, whereas in Denmark they have been found as solitary pieces in Ahrensburgian contexts, such as for example at Eskebjerg on Zealand (personal communications with Kristoffer Buck Pedersen in 2015).

Bjerck (2008: 82) dates the Norwegian Early Mesolithic period (Fosna-Hensbacka) to the timeframe of approximately 8,000-9,500 cal. BCE, whereas a date of approximately 9,70010,800 BCE has been suggested for the Danish Ahrensburgian (Buck Pedersen 2009: Fig. 110 ), roughly corresponding to the Younger Dryas chronozone.

The facts that 1) the Brodgar single-edged point is presently the only obvious representative in Scotland of this type (two pieces from western Scotland presented in Mithen et al. (2015: Fig. 8.9-10) as possible single-edged points seem to be obliquely blunted points of one or the other form); 2) that it was recovered from Orkney in northern-most Scotland; and 3) that a recently excavated site on Stronsay, Orkney, also yielded a squat tanged point of likely Norwegian type (Lee \& Woodward forthcoming; see this paper's Figure 1), indicates a possible link during the late Upper Palaeolithic-Early Mesolithic period between Northern Scotland and Scandinavia.

As indicated by Figure 9a,b, the gradual post-glacial flooding of what has become known as Doggerland (today's North Sea basin) makes a late Orkney-Scandinavia connection highly unlikely (Spinney 2012; Brooks et al. 2011; Sturt et al. 2013; Ballin in press). As singleedged points are present in Denmark, although rare, a connection with Scandinavian UP-EM material cultures would most likely have been across the Norwegian Trench, between 'Orcadian' and 'Norwegian' hunter-gatherer groups. However, as shown in Figure 9, there are different views as to the development of Doggerland between c. 16,000-8,000 BCE. Where the model presented in Figure 9a would have allowed people to walk almost the entire way from Norway to Orkney in a straight line, the model presented in Figure 9b would have required either an indirect journey along the shores of a deep embayment, travel by boat along these same shores, or possibly a journey across stable sea-ice. In the latter case, similar points may eventually be recovered from sites along most of the Scottish east-coast - it should be borne in mind that, at the present time, certain late Upper Palaeolithic finds (including artefacts from the Hamburgian, Federmesser and Ahrensburgian complexes) have only been recovered from c. a handful of sites throughout Scotland and we still know very little about this important part of Scottish prehistory. The relatively large size of the Brodgar singleedged point may also indicate an early date. 

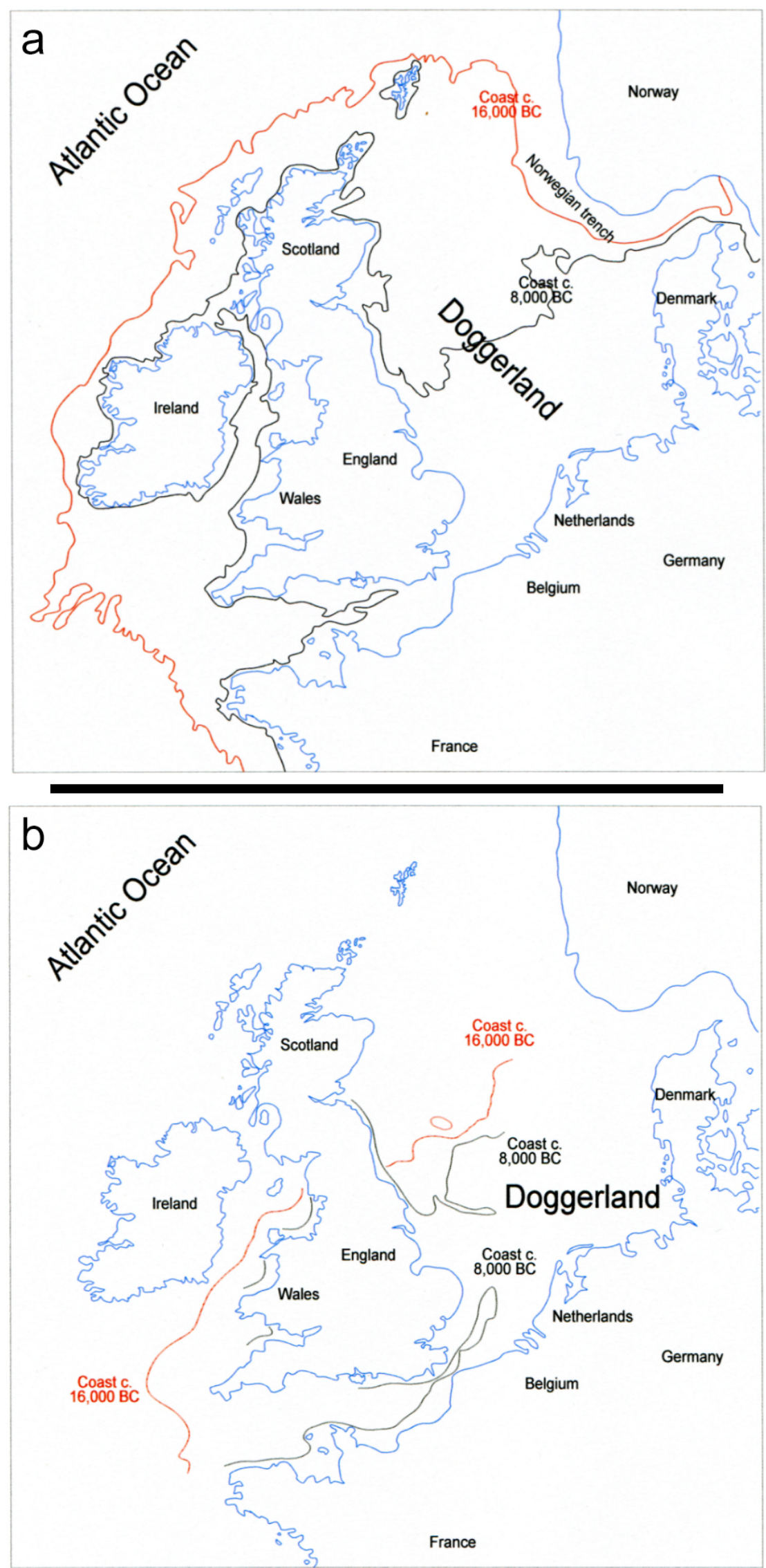

Figure 9. Maps of Doggerland, showing the staged retreat of the Doggerland coastlines, at c. 16,000 BCE and c. 8,000 BCE. a) According to Spinney (2012). b) according to Brooks et al. (2011) and Sturt et al. (2013). The red lines indicate the coast around 16,000 BCE, and the black lines around 8,000 BCE. 
It is possible that groups on either side of the Norwegian trench and the gradually forming North Sea basin may have shared economical strategies (e.g., seal hunting on sea-ice; Bjerck et al. in press) and tool kits (including armature, such as single-edged points). The stable sea-ice cover in the Late Pleistocene Doggerland-Skagerrak-Kattegat area allowed large seal populations to gather during winter and spring. It seems that all the ice-dependent seals that thrive in today's Atlantic Arctic waters were present in the Doggerland-SkagerrakKattegat region at the end of the Pleistocene, such as ringed seal (Pusa hispida), harp seal (Phoca groenlandica), bearded seal (Erignathus barbatus) and walrus (Odobenus rosmarus) (Aaris-Sørensen 2009). The sea-ice represented an extension of the continental plains that could be reached and harvested by hunters on foot, without the use of elaborate boats. After the Pleistocene-Holocene transition, this ice-related economical approach retreated northwards, following the retreat of the polar front and its associated fauna. New species of seals entered the now warmer waters of the North Sea basin, such as harbour seal (Phoca vitulina) and grey seal (Halichoerus grypus). These seal species probably flourished in the Scandinavian archipelagos, but the Holocene hunters needed seaworthy boats to catch them.

The raw material of the Brodgar point is a type of good-quality, fine-grained, homogeneous flint which is unlike the forms of low-quality, impure flint generally available in the immediate vicinity of the Orkney Islands (Harker 2002). It is also obvious that to produce the regular blade blank on which the point is based, it would have been necessary to prepare and decorticate a flint nodule somewhat larger than the present greatest dimension of the piece $(41.2 \mathrm{~mm})$, and flint pebbles found around Orkney are generally quite small. Compared to pebble-based flint artefacts from Orcadian prehistoric sites like Rinyo, Pool and Tofts Ness (inspected by Torben Bjarke Ballin), the Brodgar point is relatively large, although individual larger flint artefacts do occasionally occur on Orkney.

In Scotland, flint of this kind is usually associated with sources in the greater Yorkshire area, and it was imported into Scotland in the Hamburgian period (Ballin et al. 2010) and, later, in the Middle and Late Neolithic periods (Ballin 2011). However, it is also likely to have been available from sources across Doggerland (Harker 2002), and it may be a further indicator of possible cross-Doggerland connections.

If the Brodgar point, and some of the finds from the recently excavated Stronsay site on Orkney (Lee \& Woodward 2015), indicate the existence in the early post-glacial period of a techno-complex (Fosna-Hensbacka) which stretched from Scandinavia, across Doggerland, and into parts of north-eastern Scotland, the Scottish parts of this techno-complex may have been transformed at a relatively (as yet unspecifiable) early stage as the gradual widening of the Norwegian Trench, and the flooding of the northern parts of Doggerland, would have cut off the Scandinavian-Scottish connection. It is also important to note that the material culture recovered from Early Mesolithic contexts in Scotland is of the well-known 'standard' form, the armature of which is dominated by obliquely blunted points and isosceles triangles (Morton in Fife (Coles 1971); Donich Park in Argyll (Ballin 2012); Lussa Bay and Glenbatrick Waterhole on Jura (Mercer 1970; 1974); An Corran on Skye (Saville et al. 2012); Nethermills Farm in Aberdeenshire (Ballin 2013)). However, reliable absolute dates relating to the Scottish Early Mesolithic period are not yet available, apart from the terminus ante quem date of approximately 8,500 cal BCE suggested by the radiocarbon dates relating to the Late Mesolithic assemblage from Cramond near Edinburgh (Saville 2008). On the Norwegian 
side of the North Sea basin, no sites have yielded radiocarbon dates older than approximately 9,500 cal. BCE (Bjerck 2009).

The Fosna-Hensbacka complex is associated with other distinct formal types, such as flint flake axes, but at the present time none has been found in Scotland. This does not rule out the suggested cross-Doggerland connection but could instead indicate regional or economical differences. The Hamburgian status of the Howburn assemblage recovered in South Lanarkshire is defined as Hamburgian by its many highly typical and diagnostic Havelte (that is, Late Hamburgian) tanged points, but where a typical Continental Hamburgian assemblage would include numerous Zinken (highly diagnostic piercers with oblique tips), only a few were found at Howburn. This notable difference in terms of assemblage composition probably define regional or economical differences within the geographically extensive Hamburgian techno-complex (Ballin et al. 2010; 2015).

More work is clearly needed to shed further light on the Scottish late Upper Palaeolithic and Early Mesolithic periods, and the possible late UP-EM link between northern Scotland and Scandinavia. To explore this link further, it is suggested to compare early prehistoric lithic assemblages from either side of Doggerland or the North Sea, and a project like this would obviously benefit from involving expertise from not only Scotland but also Scandinavia.

\section{Acknowledgements}

The authors would like to thank the Hunterian Museum and Art Gallery, University of Glasgow, and in particular curator Sally-Anne Coupar, for allowing us access to the Brodgar point. We are also grateful to Marion O’Neil, National Museums Scotland, for illustrating the piece, and to Hans Kindgren, Bohusläns Museum, western Sweden, for permitting us to use his illustrations of single-edged points. We thank Hugo Anderson-Whymark for information on the refound tanged point from Millfield, Stronsay. The paper benefited from comments from two anonymous referees, as well as from curator Peter Vang Petersen, National Museum of Denmark, Dr. Mara Weber, Schloss Gottorf, Schleswig-Holstein, and Dr. Kristoffer Buck Pedersen, Museum Sydøstdanmark.

\section{References}

Aaris-Sørensen, K. 2009, Diversity and dynamics of the mammalian fauna in Denmark throughout the last glacial-interglacial cycle, 115-0 kyr BP. Fossils and Strata Vol. 57. Wiley-Blackwell, Chichester, 60 p.

Anderson-Whymark, H. (2015), Lithics. Manuscript submitted for publication. 2 p.

Ballin, T.B. 1996, Klassifikationssystem for Stenartefakter. Universitetets Oldsaksamling, Varia Vol. 36. University of Oslo, Oslo, 83 p. (in Danish) ("Classification of Lithic and Stone Artefacts")

Ballin, T.B. 2000, Classification and description of lithic artefacts. A discussion of the basic lithic terminology. Lithics 21: 9-15.

Ballin, T.B. 2002, Shieldaig, Wester Ross: The flint and bloodstone assemblage. Unpublished report commissioned by National Museums Scotland, 21 p. 
Ballin, T.B. 2011, Overhowden and Airhouse, Scottish Borders. Characterization and interpretation of two spectacular lithic assemblages from sites near the Overhowden Henge. British Archaeological Reports British Series Vol. 539. Archaeopress, Oxford, $74 \mathrm{p}$.

Ballin, T.B. 2012, Donich Park, Lochgoilhead, Argyll. Lithics from a small Early Mesolithic retooling station and a Neolithic pit cluster. Unpublished report commissioned by Argyll Archaeology, 22 p.

Ballin, T.B. 2013, The lithic assemblage from Nethermills Farm, Banchory, Aberdeenshire. Unpublished report commissioned by Aberdeen University, $46 \mathrm{p}$.

Ballin, T.B. in press, Rising waters and processes of material cultural diversification and unification - the flooding of Doggerland and its effect on NW European prehistoric populations between c. 13,000 and 1,500 cal BC. Journal of Quaternery Science (Proceedings from the Quaternary Research Association's North Sea conference in Edinburgh 2005): 15 p. doi:10.1002/jqs.2834

Ballin, T.B. \& Saville, A. 2003, An Ahrensburgian-type tanged point from Shieldaig, Wester Ross, Scotland, and its implications. Oxford Journal of Archaeology 22(2): 115-131. doi:10.1111/1468-0092.t01-1-00001

Ballin, T.B., Saville, A., Tipping, R., \& Ward, T. 2010, An Upper Palaeolithic Flint and Chert Assemblage from Howburn Farm, South Lanarkshire, Scotland: First Results. Oxford Journal of Archaeology 29(4): 323-360. doi:10.1111/j.1468-0092.2010.00352.x

Ballin, T.B., Saville, A., Tipping, R. \& Ward, T. (2015), Additional Late Hamburgian Lithic Artefacts from Howburn in South Lanarkshire, Scotland. Manuscript submitted for publication. $72 \mathrm{p}$.

Bang-Andersen, S. 1995, The Mesolithic of western Norway: prevailing problems and possibilities. In: Man and sea in the mesolithic: Coastal settlement above and below present sea level: Proceedings of the international symposium, Kalundborg, Denmark 1993 (Fischer, A., Ed.), Oxbow Monograph Vol. 53, Oxbow Books, Oxford: p. 107111. URL: http://www.nb.no/idtjeneste/URN:NBN:no-bibsys_brage_37692

Bjerck, H.B., (Ed.), 2008, NTNU Vitenskapsmuseets arkeologiske undersøkelser - Ormen Langa, Nyhamna. Tapir Akademisk Forlag, Trondheim, 659 p. (in Norwegian) ("NTNU Vitenskapsmuseets arkeologiske undersøkelser - Ormen Langa, Nyhamna")

Bjerck, H.B. 2009, Colonizing Seascapes: Comparative Perspectives on the Development of Maritime Relations in Scandinavia and Patagonia. Arctic Anthropology 46(1-2): 118131. doi:10.1353/arc.0.0019

Bjerck, H.B., Breivik, H.M., Piana, E.L. \& Zangrando, A.F. in press (June 2016), Exploring the role of pinnipeds in the human colonization of the seascapes of Patagonia and Scandinavia. In: Marine Ventures: Archaeological Perspectives on Human-Sea Relations (Proceedings from the Marine Ventures International Symposium in Trondheim 2013) (Bjerck, H.B., Breivik, H.M., Fretheim, S.E., Piana, E.L., Skar, B., Tivoli, A.M. \& Zangrando, A.F., Eds.), Equinox Publishing Ltd., Sheffield: 15 p. doi:10.1558/equinox.24552

Bohmers, A. 1956, Statistics and Graphs in the Study of Flint Assemblages. Palaeohistoria, 5: 1-38. URL: http://bjournals.ub.rug.nl/palaeohistoria/issue/view/70

Breivik, H.M.B., H.B. (2015), Early Mesolithic central Norway: A review of research history, settlements, and tool tradition. Manuscript submitted for publication. $14 \mathrm{p}$. 
Brooks, A.J., Bradley, S.L., Edwards, R.J. \& Goodwyn, N. 2011, The palaeogeography of Northwest Europe during the last 20,000 years. Journal of Maps, 7(1): 573-587. doi:10.4113/jom.2011.1160

Buck Pedersen, K. 2009, Stederne og menneskene: Istidsjæegere omkring Knudshoved Odde. Museerne.dk Vol. 3. Museerne.dk, Vordingborg, 151 p. (in Danish) ("The sites and the people. Ice Age hunters at the point of Knudshoved Odde")

Card, N. (2013). Ness of Brodgar - more than a stone circle. British Archaeology, 128 (January/February), 14-21. URL: http://www.britisharchaeology.org/ba128

Clark, J.G.D. 1933, The Classification of a Microlithic Culture: The Tardenoisian of Horsham. Archaeological Journal, 90(1): 52-77. doi:10.1080/00665983.1933.10853603

Clausen, I. 1996, Alt Duvenstedt LA 121, Schleswig-Holstein - occurrence of the Ahrensburgian culture in soils of the Alleröd interstadial: A preliminary report. In: The Earliest Settlement of Scandinavia (Larsson, L., Ed.), Acta Archaeologica Lundensia Vol. 24, Lunds Universitet, Stockholm: p. 99-110.

Coles, J.M., Allo, J., Candow, R.D.M., Clegg, T.M., Cowles, G.S., Hibbert, F.A., Higgs, E.S., Jarman, M.R., Laing, D., Mcmanus, J., Pettit, M., Switsur, R., Taylor, C.B., Wheeler, A., Whyte, F. \& Wilson, G. 1971, The Early Settlement of Scotland: Excavations at Morton, Fife. Proceedings of the Prehistoric Society, 37(02): 284-366. doi:10.1017/S0079497X00012688

Edwards, K.J. \& Mithen, S. 1995, The colonization of the Hebridean Islands of Western Scotland: Evidence from the palynological and archaeological records. World Archaeology, 26(3): 348-365. doi:10.1080/00438243.1995.9980281

Finlayson, B. 1998, Wild Harvesters. The First People in Scotland. Canongate Books and Historic Scotland, Edinburgh, 64 p.

Fischer, A. 1978, På sporet af overgangen mellem palaeoliticum og mesoliticum i Sydskandinavien. Hikuin, 4: 27-50. (in Danish) ("Defining the transition of the Palaeolithic/Mesolithic transition in southern Scandinavia")

Fischer, A. 1991, Pioneers in deglaciated landscapes: the expansion and adaptation of Late Palaeolithic socities in southern Scandinavia. In: The Late Glacial in north-west Europe: Human adaptation and environmental change at the end of the Pleistocene (Barton, N., Roberts, A.J. \& Roe, D.A., Eds.), CBA Research Report Vol. 77, Council for British Archaeology, London: p. 100-121.

Fischer, A., Hansen, P.V. \& Rasmussen, P. 1984, Macro and Micro Wear Traces on Lithic Projectile Points. Journal of Danish Archaeology, 3(1): 19-46. doi:10.1080/0108464X.1984.10589910

Harker, S. 2002, Cretaceous. In: The Geology of Scotland (Trewin, N.H., Ed.), The Geological Society, London: p. 351-360.

Helskog, K., Indrelid, S., \& Mikkelsen, E. 1976, Morfologisk klassificering av slåtte steinartefakter. Universitetets Oldsaksamling, Årbok, 1972-1974: 9-52. (in Norwegian) ("Formal classification of struck lithic artefacts") 
The Hunterian Museum and Art Gallery 2006, Hunterian Museum Archaeology \& Ethnography Collections: GLAHM B.1914.709/1. University of Glasgow. Retrieved 16 January 2016. URL: http://www.huntsearch.gla.ac.uk/cgibin/foxweb/huntsearch/DetailedResults.fwx?collection=archaeology\&SearchTerm=B.1 914.709/1

Inizan, M.-L., Roche, H. \& Tixier, J. 1992, Technology of Knapped Stone. Cercle de Recherches et d'Etudes Préhistoriques, Meudon, 127 p.

Jensen, J. 2006, Danmarks Oldtid. Stenalder 13.000 - 2.000 f. Kr. Gyldendal, Copenhagen, 620 p. (in Danish) ("The prehistory of Denmark. The Stone Age 13,000-2,000 BCE")

Kankaanpää, J. \& Rankama, T. 2011, Spatial patterns of the Early Mesolithic Sujala site, Utsjoki, Finnish Lapland. In: Mesolithic Interfaces: Variability in lithic technologies in Eastern Fennoscandia (Rankama, T., Ed.), Monographs of the Archaeological Society of Finland Vol. 1, The Archaeological Society of Finland, Saarijärvi: p. 42-63. URL: http://www.sarks.fi/masf/masf_1/MI_02_Kankaanpaa_Rankama.pdf

Kindgren, H. 2002, Tosskärr. Stenkyrka 94 revisited. In: Recent studies in the Final Palaeolithic of the European plain (Eriksen, B.V. \& Bratlund, B., Eds.), Jutland Archaeological Society, Højbjerg: p. 49-60.

Lee, D.H.J. \& Woodward, N.L., (Eds.) (2015), Mesolithic occupation at Links House, Stronsay, Orkney c. 7000 cal BC: The first structural evidence for the Northern Isles of Scotland. Unpublished edited volume. $77 \mathrm{p}$.

Livens, R.G. 1956, Three tanged flint points from Scotland. Proceedings of the Society of Antiquaries of Scotland 89: 438-43.

URL: http://archaeologydataservice.ac.uk/archiveDS/archiveDownload?t=arch-3521/dissemination/pdf/vol_089/89_438_443.pdf

Mercer, J. 1970, Flint Tools from the Present Tidal Zone, Lussa Bay, Isle of Jura, Argyll. Proceedings of the Society of Antiquaries of Scotland 102: 1-30.

URL: http://archaeologydataservice.ac.uk/archiveDS/archiveDownload?t=arch-3521/dissemination/pdf/vol_102/102_001_030.pdf

Mercer, J. 1974, Glenbatrick Waterhole, a microlithic site on the Isle of Jura. Proceedings of the Society of Antiquaries of Scotland 105: 9-32.

URL: http://archaeologydataservice.ac.uk/archiveDS/archiveDownload?t=arch-3521/dissemination/pdf/vol_105/105_009_032.pdf

Mithen, S., Wicks, K., Pirie, A., Riede, F., Lane, C., Banerjea, R., Cullen, V., Gittins, M. \& Pankhurst, N. 2015, A Lateglacial archaeological site in the far north-west of Europe at Rubha Port an t-Seilich, Isle of Islay, western Scotland: Ahrensburgian-style artefacts, absolute dating and geoarchaeology. Journal of Quaternary Science, 30(5): 396-416. doi:10.1002/jqs.2781

Morrison, A. \& Bonsall, C. 1989, The Early Post-Glacial Settlement of Scotland: a Review. In: The Mesolithic in Europe: Papers Presented at the Third International Symposium, Edinburgh 1985 (Bonsall, C., Ed.), John Donald Publishers Ltd., Edinburgh: p. 134142.

Møllenhus, K.R. 1977, Mesolitiske Boplasser på Møre- og Trøndelagskysten. Gunneria Vol. 27. Det Kongelige Norske Videnskabers Selskab, Museet, Trondheim, 216 p. (in Norwegian) ("Mesolithic settlements along the coast of Møre og Trøndelag counties") 
Saville, T.B. 1996, Lacaille, Microliths and the Mesolithic of Orkney. In: The Early Prehistory of Scotland (Pollard, T. \& Morrison, A., Eds.), Edinburgh University Press, Edinburgh: p. 213-224.

Saville, A. 2000, Orkney and Scotland before the Neolithic period. In: Neolithic Orkney in its European Context (Ritchie, A., Ed.), McDonald Institute Monographs, McDonald Institute for Archaeological Research, Cambridge, U.K.: p. 91-100.

Saville, A. 2004, The Material Culture of Mesolithic Scotland. In: Mesolithic Scotland and its Neighbours: The Early Holocene Prehistory of Scotland, its British and Irish Context, and some Northern European Perspectives (Saville, A., Ed.), Society of Antiquaries of Scotland, Edinburgh: p. 185-220.

Saville, A. 2008, The Beginning of the Later Mesolithic in Scotland. In: Man - Millennia Environment. Studies in Honour of Romuald Schild (Sulgostowska, Z. \& Tomaszewski, A.J., Eds.), Institute of Archaeology and Ethnology, Polish Academy of Sciences, Warsaw: p. 207-213.

Saville, A., Hardy, K., Miket, R. \& Ballin, T.B. 2012, An Corran, Staffin, Skye: a Rockshelter with Mesolithic and Later Occupation. Scottish Archaeological Internet Reports Vol. 51. Society of Antiquaries of Scotland, Edinburgh.

URL: http://archaeologydataservice.ac.uk/archives/view/sair/contents.cfm?vol=51

Schwabedissen, H. 1954, Die Federmesser- Gruppen des nordwesteuropäischen Flachlandes, zur Ausbreitung des Spät-Magdalénien. Karl Wachholtz Verlag, Neumünster, 104 p. (in German) ("The Federmesser Complex of the North-West European plain")

SFLPS (Scapa Flow Landscape Partnership Scheme) 2011, The Mesolithic. Scapa Flow Landscape Partnership Scheme. Retrieved 16 January 2016. URL:

http://www.scapaflow.co/index.php/history_and_archaeology/the_mesolithic/sites

Shepherd, W. 1972, Flint: Its origin, properties and uses. Faber and Faber, London, 256 p.

Spinney, L. (2012). The Lost World of Doggerland. National Geographic, 222 (6), 132-143.

Sturt, F., Garrow, D. \& Bradley, S. 2013, New models of North West European Holocene palaeogeography and inundation. Journal of Archaeological Science, 40(11): 39633976. doi:10.1016/j.jas.2013.05.023

Sørensen, M., Rankama, T., Kankaanpää, J., Knutsson, K., Knutsson, H., Melvold, S., Eriksen, B.V. \& Glørstad, H. 2013, The First Eastern Migrations of People and Knowledge into Scandinavia: Evidence from Studies of Mesolithic Technology, 9th-8th Millennium BC. Norwegian Archaeological Review, 46(1): 19-56. doi:10.1080/00293652.2013.770416

Taute, W. 1968, Die Stielspitzen-Gruppen im nördlichen Mitteleuropa: Ein Beitrag zur Kenntnis der späteren Altsteinzeit. Fundamenta A/5. Böhlau Verlag, Cologne, 326 p. (in German) ("The tanged point industries of northern Central Europe: A contribution to the investigation of the late Upper Palaeolithic period")

Towers, R., Card, N., \& Edmonds, M. 2015, The Ness of Brodgar. Orkney Media Group, Kirkwall, 32 p.

Tizzard, L., Bicket, A. \& De Loecker, D. 2015, Seabed Prehistory: Investigating the Palaeogeography and Early Middle Palaeolithic Archaeology in the Southern North Sea. Wessex Archaeology Report Vol. 35. Wessex Archaeology Ltd., Salisbury, 152 p. 
Vang Petersen, P. 1999, Flint fra Danmarks oldtid. Høst \& Søn, Copenhagen, 154 p. (in Danish) ("Flint from Danish prehistory")

Vang Petersen, P. \& Johansen, L. 1991, Sølbjerg I - An Ahrensburgian Site on a Reindeer Migration Route through Eastern Denmark. Journal of Danish Archaeology, 10(1): 2037. doi:10.1080/0108464X.1991.10590051

Wickham-Jones, C.R. 1994, Scotland's First settlers. Historic Scotland, Edinburgh, 128 p.

Wickham-Jones, C.R. \& Firth, C.R. 2000, Mesolithic settlement of northern Scotland: First results of fieldwork in Caithness and Orkney. In: Mesolithic lifeways: Current research from Britain and Ireland (Young, R., Ed.), Leicester Archaeology Monographs Vol. 7, University of Leicester, School of Archaeological Studies, Leicester: p. 119-132. 